Original Article

\title{
LEAD MOLECULE IDENTIFICATION FROM VITEX TRIFOLIA LINN FOR HELMINTHIASIS USING IN VITRO AND IN SILICO METHODS
}

\author{
SOUNDARARAJAN MUTHUKRISHNAN ${ }^{1,2,4 *}$, RAGUNATH G.1,3, BLESSY SUSAN VARGHESE1
}

${ }^{* 1}$ Department of Pharmacology, Sankaralingam Bhuvaneshwari College of Pharmacy, Sivakasi, TamilNadu, India, ${ }^{2}$ Department of Pharmacology, Karavali College of Pharmacy, Mangalore, India, ${ }^{3}$ Department of Pharmacology, Kamalakshi Pandurangan College of Pharmacy, Thiruvannamalai, India, ${ }^{4}$ Department of Pharmacy, Annamalai University, Chidambaram, Tamil Nadu, India

Email: s.muthukrishnan.smk@gmail.com

Received: 13 Nov 2019, Revised and Accepted: 25 Dec 2019

\section{ABSTRACT}

Objective: The study was an attempt to discover a lead molecule to treat helminthiasis using Vitex trifolia. Linn ( $V$. folia Linn) through sterile effect, in vitro and in silico evaluation.

Methods: The antibacterial activity was done by Kirby-Bauer disc diffusion method in three different concentrations of extract and in vitro anthelmintic activity was carried out by petri dish and organ bath method. Further, the in silico docking studies were carried out by 11 phytoconstituents against phosphoethanolamine methyltransferase (4FGZ) using Auto Dock 4.2, it was working based on the principle of Lamarckian genetic algorithm. In docking studies, three important parameters such as binding energy, inhibition constant and intermolecular energy are determined.

Results: The extracts showed an antibacterial effect in three different concentrations. At $16 \mathrm{mcg} /$ disc a significant effect was observed when compared to blank and ciprofloxacin $5 \mathrm{mcg} /$ disc. The anthelmintic activity in the petri dish method, means paralyzing time of Pheretima posthuma with the dose of 25, 50 and $100 \mathrm{mg} / \mathrm{ml}$ were $13.78,5.79$ and $4.57 \mathrm{~min}$ respectively and Piperazine citrate $(10 \mathrm{mg} / \mathrm{ml})$ showed paralysis in 21.58 min. In the organ bath method, the time for paralysis of the worm was recorded on a slow-moving Sherrington rotating drum and the study report showed that paralyzing time was decreased at increasing concentrations of the extract. The results of in silico studies exhibited a binding energy of$10.25 \mathrm{kcal} / \mathrm{mol}$, inhibitory constant $(\mathrm{Ki}) 30.91 \mathrm{nM}$, intermolecular energy, $-10.84 \mathrm{kcal} / \mathrm{mol}$ for abietatriene-3-ol which is lesser than the standard ligand phosphoethanolamine $(-6.03 \mathrm{kcal} / \mathrm{mol}, 38.29 \mu \mathrm{M},-7.82 \mathrm{kcal} / \mathrm{mol})$ respectively.

Conclusion: The study reports conclude that the active constituents in $V$. folia Linn having better anthelmintic activity, thus the active constituents may be optimized and make way to a new moiety for the treatment of helminthiasis.

Keywords: V. trifolia, Helminthiasis, Binding energy, Inhibitory constant, Intermolecular energy, Phosphoethanolamine methyltransferase, Abietatriene-3-ol, Phosphorethanolamine

(C) 2020 The Authors. Published by Innovare Academic Sciences Pvt Ltd. This is an open access article under the CC BY license (http://creativecommons.org/licenses/by/4.0/) DOI: http://dx.doi.org/10.22159/ijpps.2020v12i2.36353. Journal homepage: https://innovareacademics.in/journals/index.php/ijpps

\section{INTRODUCTION}

Helminthiasis is one of the major public health issues across many countries. Anthelmintic drugs have been the only effective method of controlling worm infestations, but there is now widespread parasite resistance to most of the commercially available drugs $[1,2]$. The development of resistance to a group of anthelmintics poses a challenge to identify novel molecular targets for helminthiasis $[1,2]$. Various synthetic compounds have been proved to have anthelmintic activity. Some of the natural products have been proved to have anthelmintic activity but their safety profile is not favorable. So current research is focussed on natural products having an anthelmintic activity that may be useful in helminthiasis. $V$. folia Linn (Family: Verbenaceae) in English is named as threeleaved chase tree, called Nirnocci Sirunocci in Tamil. The leaves, roots, essential oils parts are mostly used as a dried whole plant are used in the traditional system of medicine. It is a stout aromatic found throughout the greater part of India, Western Ghats, and Himalaya southwards. It is a shrub or small tree with a growing height of about 1 to 4 meters. The leaves of the 3-foliolate of Vitex negundo closely resemble $V$. trifolia $[3,4]$. These leaves are used for rheumatic pain and inflammation $[5,6]$ and have, anti-convulsant, sedatives-hypnotic activity [7] etc. This plant has already proven its free radical scavenging and in vitro antioxidant activity [8], hepatoprotective activity [9], wound healing activity [10] and anticancer activity [11]. The prime active constituents of the plant are isabietatriene-3-ol, beta-sitosterol, dihydrosolidagenone, friedelin, isovitexin, rotundiduran, vitetrifolin-A, vitetrifolin-B, vitetrifolin-C, vitexycarpin [12-14]. The nematodes plasma membrane nematodes biosynthesized from phosphatidylcholine [2]. This phosphatidylcholine serves as a precursor for the production of glycol, reverted by the nematodes to avoid host immune response. In phosphatidylcholine biosynthesis, phosphoethanolamine methyltransferase enzyme is responsible for methylation of phosphatase $[15,16]$. The Plasmodium falciparum of phosphoethanolamine methyltransferase (4FGZ) possesses a single methyl-transferase domain that methylates all three phosphatases $[17,18]$ and has been shown to be essential for the growth and sexual reproduction of the parasite [19]. In silico molecular docking technique plays an important role in the drug design and discovery to predict the conformations of each ligand molecule at the active site; hence, the in silico (molecular docking) studies of newly synthesized compounds. We have carried out the evaluation of phosphoethanolamine methyltransferase inhibitory activity of those phytoconstituents present in $V$. trifolia Linn and results are reported. The objective of the present study is an attempt to the in vitro anthelmintic and antibacterial studies of total methanolic leaf extract of $V$. trifolia Linn and examine its activities phosphoethanolamine methyltransferase inhibitory activity of its phytoconstituents by in silico docking studies using AutoDock 4.2

\section{MATERIALS AND METHODS}

Collection and processing of plant material

The $V$. folia Linn leaves were collected in the month of December 2015, from our college botanical garden in Anaikuttam, Sivakasi, Tamilnadu. Then it's authenticated by Mr. V. Ganesan, M. Sc., Ph. D., Associate professor, and Head, a center for research and PG studies 
in botany, Ayyanadar Janaki Ammal College, Sivakasi, Tamilnadu, India. A voucher specimen (number: 2015/12/COG012) has been maintained in our lab for future reference.

\section{Preparation of crude extracts}

The leaves of $V$. folia Linn after the collection was cleaned and removed of the adhering materials and allowed to shade dried, coarsely powdered and first extracted with hexane for removal of fatty and coloring material, then marc was dried and packed in the Soxhlet extractor. The packed material was extracted successively with methanol. After completion of the extraction, these extracts were allowed to undergo the distillation process for recovering the solvent and concentrate the extract. The concentrated extract was dried under vacuum in desiccators containing anhydrous calcium chloride. The dried products were weighed in order to determine the percentage of yield. The color and consistency were noted and the percentage yield was calculated [20].

\section{Animal and instruments}

In Indian adult earthworm (Pheretima posthuma) was chosen for this study, due to its anatomical and physiological resemblance with the intestinal roundworm parasites of human beings [21]. Student's organ bath (it's consists of an outer jacket, made up of Perspex; the inner organ bath made up of glass with a capacity $40 \mathrm{ml}$, length 40 $\mathrm{cm}$ and width $6 \mathrm{~cm}$; thermostatically controlled heating rod; stirrer, glass coil, and tissue holder), Sherrington rotating drum and frontal writing lever for the organ bath method.

\section{Details of software}

Python 2.7-language was downloaded from www. python. com, Cygwin (data storage) c: \program and Python 2.5 were simultaneously downloaded from www. cygwin. com, Molecular graphics laboratory (MGL) tools and Auto Dock 4.2 was downloaded from www. scripps. edu, Discovery studio visualizer 2.5.5 was downloaded from www. accelerys. com, Molecular orbital package (MOPAC), Chemsketch was downloaded from www. acdlabs. com. Online smiles translation was carried out using cactus. nci. nih. gov/translate/[22, 23]

\section{Determination of extraction yield (\% yield)}

The yield $(\%, \mathrm{w} / \mathrm{w})$ from all the dried extracts was calculated as:

$$
\text { Percentage yield }(\%)=(\mathrm{W} 1 * 100) / \mathrm{W} 2
$$

Where $W_{1}$ is the weight of the extract obtained after evaporation of the solvent; and $W_{2}$ is the weight of the plant powder. The extracts were kept in airtight containers to avoid the loss of any volatile principles or/and activities until further use.

\section{Antibacterial activity}

Antibacterial screening was carried out in the total methanolic leaf extract of $V$. trifolia by Kirby-Bauer disc diffusion method in three different concentrations ( $4 \mu \mathrm{g}, 8 \mu \mathrm{g}, 16 \mu \mathrm{g} /$ disc) against organisms such as Shigella, staphylococcus, streptococci, Streptococcus pneumoniae (gram-positive) Haemophilus influenzae, klebsiella, Proteusvulgaris and Salmonella typhi (gram-negative). Inoculation on Mueller-Hinton agar plate was done by the streaking technique method. The entire agar surface was streaked with the help of a sterile cotton swab and allowed for 5 min to dry the inoculum. The Sterile paper disc, impregnated with the total methanolic leaf extracts $(200,400$ and $800 \mu \mathrm{g} / \mathrm{ml})$ was placed on the surface of the medium in each petri dish. Negative control discs with solvent (DMF) and standard discs with ciprofloxacin $5 \mu \mathrm{g}$ were also placed in each petri dish and incubated for $18 \mathrm{~h}$ at $37^{\circ} \mathrm{C}$. After incubation, the diameter of the zone of inhibitions (in $\mathrm{mm}$ ) was recorded. This zone of inhibition value was compared with standard ciprofloxacin $5 \mu \mathrm{g} /$ disc and solvent blank [24].

\section{In vitro anthelmintic assay}

The anthelmintic activity was evaluated in Indian adult earthworm (Pheretima posthuma) due to its anatomical and physiological resemblance with the intestinal roundworm parasites of human beings [21, 25] by Devi et al. method [26]. Piperazine citrate served as a standard drug $(10 \mathrm{mg} / \mathrm{ml})$, dimethylformamide used as a co-solvent for the extract, saline as a solvent blank, student's organ bath (it's consist of an outer jacket, made up of Perspex; the inner organ bath made up of glass with a capacity $40 \mathrm{ml}$, length $40 \mathrm{~cm}$ and width $6 \mathrm{~cm}$; thermostatically controlled heating rod; stirrer, glass coil, and tissue holder) Sherrington rotating drum and Frontal writing lever were used.

\section{Petri dish method}

Pheretima posthuma was placed in a petri dish containing three different concentrations $(25,50,100 \mathrm{mg} / \mathrm{ml})$ of a total methanolic leaf extract of $V$. trifolia solutions; Piperazine citrate $(10 \mathrm{mg} / \mathrm{ml})$ was used as a standard reference and saline served as a solvent blank. Nearly equal-sized Indian earthworms were divided into five groups, each group consisting of four earthworms. These worms were released into $50 \mathrm{ml}$ of sample and standard solution and observed the worms. The compound having anthelmintic property would produce paralysis (or) death. The time of paralysis of individual worms was noted. The paralyzed worms that not recover in normal saline were considered as dead $[26,27]$.

\section{Organ bath method}

Anthelmintic assay in the organ bath method was carried as per the method reported by Danquah et al. 2012 with minor modifications [28].

All the extracts and the standard drug solution were freshly prepared during the experiment. In this method, the experiment was carried out in the student's organ bath. Before starting the experiment the heating rod was switched off, the outer jacket of the student's organ bath was filled with cold water to sense the worm in humid condition. Assemble the Sherrington rotating drum was assembled; kymograph and adjust the frontal writing lever were adjusted to a magnification value below 5 for recording the response. The lower part of the worm was tied to the hook of the tissue holder using a piece of thread; the upper part was also tied to the recording lever using thread. Oxygen was bubbled through the aeration tube make sure aeration doesn't interrupt the response. With sufficient counterweight applied to the lever, the worm was kept upright in the organ bath. The responses were recorded in smoked papers fixed to the drum. The speed of the drum was adjusted to $0.12 \mathrm{~mm} / \mathrm{Sec}$ by changing the gear in Sherrington rotating drum. Let replace the water using normal saline an organ bath, spontaneous movement of the worm was recorded in kymograph this response served as a control. Then the response of worms in the presence of standard drug Piperazine citrate $(10$ $\mathrm{mg} / \mathrm{ml}$ ) and various concentrations of total methanolic leaf extract of $V$. trifolia $25,50,100 \mathrm{mg} / \mathrm{ml}$ was recorded, the fresh worm was used for every procedure. Time for paralysis (seen as a decrease in spontaneous movement and no movement respectively) of the worm was recorded on a slow-movingSherrington rotating drum. Declined response represented the termination of the experiment.

\section{Molecular docking study}

Molecular simulation based on docking was performed using Autodock 4.2 software package. For the docking studies, the structures of the compounds were generated from Chemsketch software. The known crystal structure of the enzyme (PDB ID: 4FGZ) was obtained from the Protein Data Bank. Autodock 4.2 suite of programs which utilizes the Lamarckian Genetic Algorithm was implemented for the docking studies of phosphoethanolamine methyltransferase inhibitor activity. In the initial stage of docking, all the water molecules were removed and the hydrogen atoms were added, followed by computing Gasterger charges, as required in the Lamarckian Genetic Algorithm. For the docking analysis, the grid size was set to $70 \AA, 70 \AA$ and $70 \AA \AA$ along $\mathrm{X}, \mathrm{Y}$ and $\mathrm{Z}$-axis with $0.375 \AA$ grid spacing. The docking parameters used were as follows: GA population size $=100$ and the maximum number of energy evaluation $=2,500,000$, other parameters used were default values. The lowest binding energy conformation was searched out and used for further analysis [29-31].

\section{Statistical analysis}

The data obtained were expressed as mean \pm SEM. Statistical analysis was performed by one-way analysis of variance (ANOVA) followed 
by Dunnett'st-test. At $95 \%$ confidence interval, $p$ values $<0.001$ were considered significant [31].

\section{RESULTS}

\section{Extraction yield (\% yield) of the various extracts}

The percentage yield of the total methanolic extract of $V$. trifolia was $31.12 \% \mathrm{w} / \mathrm{w}$. Its greenish-black color and sticky in nature. The extracts were kept in airtight containers to avoid the loss of any volatile principles or/and activities until further use.

\section{Evaluation of antibacterial activity}

The antibacterial screening was carried out in the total methanolic leaf extract of $V$. trifolia by Kirby-Bauer Disc Diffusion Method in three different concentrations ( $4 \mu \mathrm{g}, 8 \mu \mathrm{g}, 16 \mu \mathrm{g} / \mathrm{disc})$ against various gram-positive and gram-negative bacteria, then the diameter (in $\mathrm{mm}$ ) of the zone of inhibition was recorded. This zone of inhibition value was compared with standard ciprofloxacin
$5 \mu \mathrm{g} /$ disc and solvent blank. All the selected concentration ( $4 \mu \mathrm{g}$, 8 $\mu \mathrm{g}, 16 \mu \mathrm{g} / \mathrm{disc})$, standard drug ciprofloxacin (5 $\mu \mathrm{g} / \mathrm{disc})$ significantly inhibited the bacterial growth, but the solvent blank disc did not inhibit the bacterial growth against both gram-positive and gramnegative bacteria (fig. 1). Thus indicating that the extract had antibacterial activity. All the selected concentrations showed antibacterial efficacy, particularly $16 \mu \mathrm{g} /$ disc of $V$. trifolia extract showed potent inhibition against all the eight strains when compared with 4, $8 \mu \mathrm{g} /$ disc. From the observation, the zone of inhibition (ZOI) was measured and it has been tabulated (table 1) and it was found that the ZOI of the extract was found to be varying between 7-14 mm, with respect to most of the test bacteria. A comparison with solvent blank

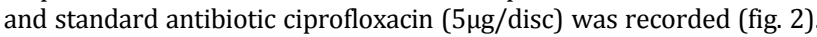
From the results of ZOI values and their comparison to that of the standard ciprofloxacin, it is evidenced that the total methanolic extract of $V$. trifolia was effective against gram-positive and gram-negative bacteria. The phytoconstituents of the plant may be responsible for this antibacterial activity.

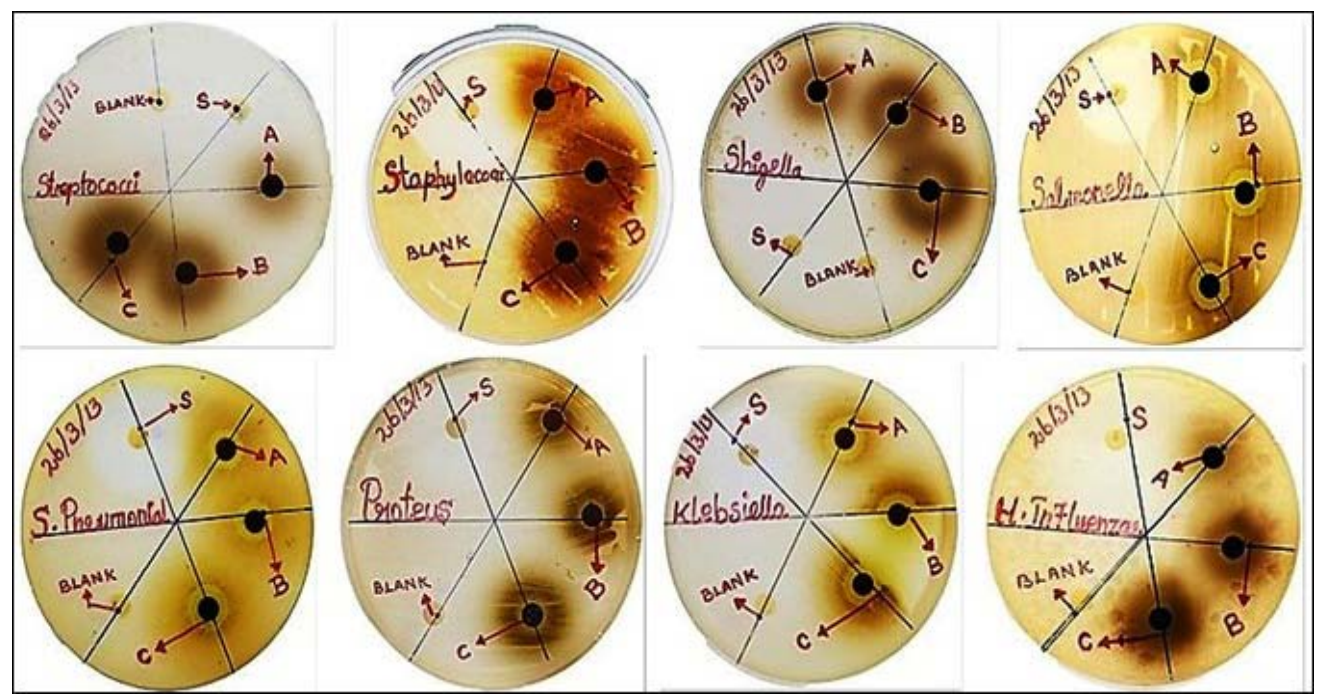

Fig. 1: Antibacterial activity of the total methanolic leaf extract of Vitex trifolia against various bacterial strains by kirby-bauer disc

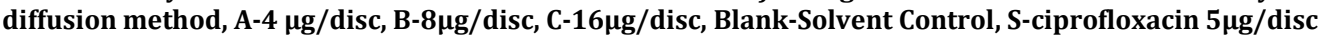

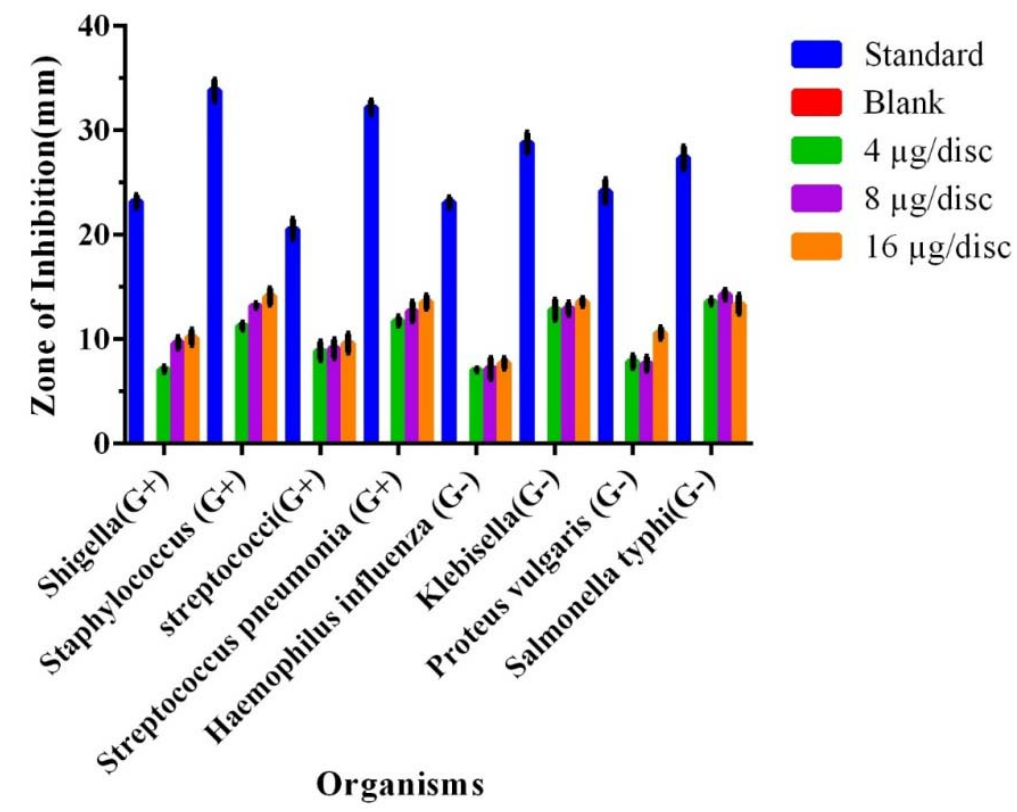

Fig. 2: Antibacterial activity of various concentrations of total methanolic leaf extract of Vitex trifolia against various bacterial strains by Kirby-bauer disc diffusion method 
Table 1: Antibacterial activity of total methanolic leaf extract of Vitex trifolia against various bacterial strains by Kirby-Bauer disc diffusion method

\begin{tabular}{|c|c|c|c|c|c|}
\hline \multirow[t]{3}{*}{ Organism } & \multicolumn{5}{|l|}{ Zone of inhibition (in mm) } \\
\hline & \multirow{2}{*}{$\begin{array}{l}\text { Standard } \\
\text { (Ciprofloxacin } 5 \mu \mathrm{g} / \text { disc) }\end{array}$} & \multirow[t]{2}{*}{ Blank } & \multicolumn{3}{|c|}{ Total methanolic extract of Vitex trifolia } \\
\hline & & & $4 \mu \mathrm{g} / \mathrm{disc}$ & $8 \mu \mathrm{g} / \mathrm{disc}$ & $16 \mu \mathrm{g} / \mathrm{disc}$ \\
\hline Shigella $\left(\mathrm{G}^{+}\right)$ & $23.22 \pm 0.61$ & - & $7.12 \pm 0.25$ & $9.65 \pm 0.54$ & $10.20 \pm 0.72$ \\
\hline Staphylococcus $\left(\mathrm{G}^{+}\right)$ & $33.85 \pm 1.02$ & - & $11.28 \pm 0.35$ & $13.23 \pm 0.25$ & $14.11 \pm 0.76$ \\
\hline streptococci $\left(\mathrm{G}^{+}\right)$ & $20.56 \pm 0.95$ & - & $8.89 \pm 0.89$ & $9.11 \pm 0.88$ & $9.62 \pm 0.88$ \\
\hline Streptococcus pneumonia $\left(\mathrm{G}^{+}\right)$ & $32.23 \pm 0.67$ & - & $11.75 \pm 0.45$ & $12.64 \pm 0.92$ & $13.57 \pm 0.64$ \\
\hline Haemophilus influenza (G-) & $23.11 \pm 0.52$ & - & $7.05 \pm 0.15$ & $7.21 \pm 1.02$ & $7.72 \pm 0.51$ \\
\hline Klebisella(G-) & $28.83 \pm 0.97$ & - & $12.86 \pm 0.97$ & $12.94 \pm 0.58$ & $13.59 \pm 0.37$ \\
\hline Proteus vulgaris (G-) & $24.18 \pm 1.12$ & - & $7.87 \pm 0.61$ & $7.64 \pm 0.67$ & $10.61 \pm 0.54$ \\
\hline Salmonella typhi(G-) & $27.38 \pm 1.09$ & - & $13.63 \pm 0.28$ & $14.28 \pm 0.46$ & $13.34 \pm 0.90$ \\
\hline
\end{tabular}

G+-Gram-Positive Bacteria, G--Gram-Negative Bacteria, Each value was represented as mean \pm SEM, $n=6$ independent experiments
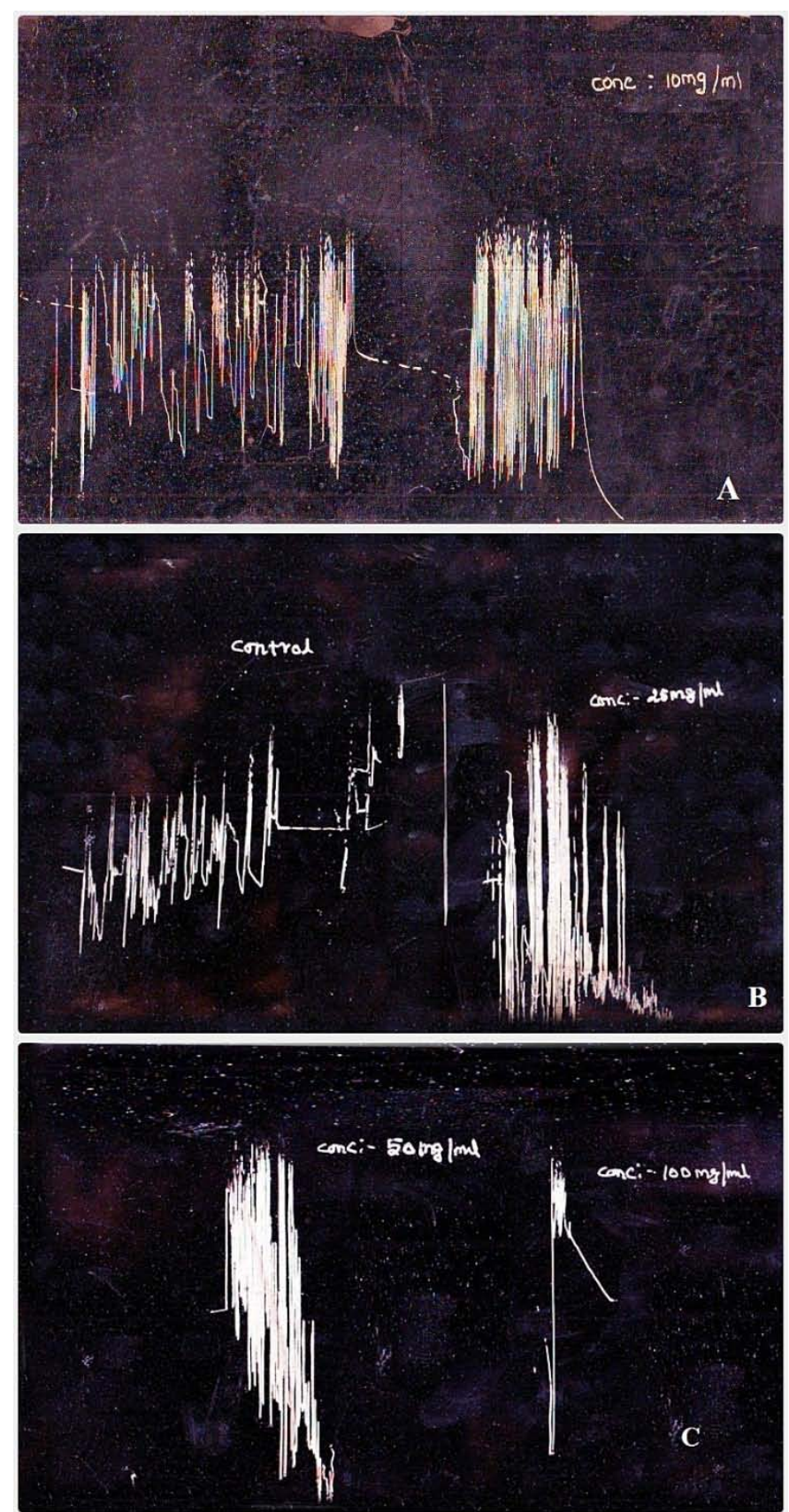

Fig. 3: Anthelmintic activity of the total methanolic leaf extract of vitex trifolia Linn against Indian adult worms (Pheretima posthuma) by organ bath method, A-Paralysing Response of $P$. posthuma against saline and Piperazine citrate (10 mg/ml), B and C-Paralysing Response of $P$. posthuma against saline and total methanolic leaf extract of Vitex trifolia at different concentrations (25, 50, 100 mg/ml) 


\section{In vitro anthelmintic assay}

\section{Anthelmintic activity by petri dish method}

Anthelmintic activity was carried out for three different concentrations $(25,50,100 \mathrm{mg} / \mathrm{ml})$ a total methanolic leaf extract of $V$. trifolia by petri dish method against adult Indian worms Pheretimaposthuma, Piperazine citrate $(10 \mathrm{mg} / \mathrm{ml})$ was used as a standard reference. Observations were made for the time of paralysis of individual worms against at various concentrations of the extract and standard. Paralysis was assumed to have occurred when the worms did not revive even in normal saline. The selected three concentrations $(25,50,100 \mathrm{mg} / \mathrm{ml})$ produced an anthelmintic activity (table 2). The anthelmintic activity increased in a dosedependent manner.

\section{Anthelmintic activity by organ bath method}

Earthworms are invertebrates composed of many segments. It has a special layer that being slimy, enables the earthworm for spontaneous movement. This motility response was recorded in the presence of standard drug Piperazine citrate $(10 \mathrm{mg} / \mathrm{ml})$ and various concentrations of total methanolic leaf extract of $V$. trifolia $25,50,100 \mathrm{mg} / \mathrm{ml}$, the fresh worm was used for every sample. The worms were treated with standard drug Piperazine citrate (10 $\mathrm{mg} / \mathrm{ml}$ ) and various concentration of total methanolic leaf extract of $V$. trifolia 25, 50, $100 \mathrm{mg} / \mathrm{ml}$. The motility of the worms was recorded in kymograph during the treatment (fresh worms were used for every sample).

As shown in fig. 3 the worms showed normal spontaneous movement in saline treatment. On treatment with a standard drug (Piperazine citrate $(10 \mathrm{mg} / \mathrm{ml})$ and various concentrations of methanolic extract of $V$. trifolia $25,50,100 \mathrm{mg} / \mathrm{ml}$ worms muscle started to paralyze which was represented in the response in kymograph, by a declined response from baseline graph (table 2). All the selected concentrations $(25,50,100 \mathrm{mg} / \mathrm{ml})$ significantly produced a paralyzing effect on worms. At the same time, worms showed quick paralysis time was very short in high concentration. So it produced the anthelmintic activity in a dose-dependent manner.

Table 2: Anthelmintic activities of the total methanolic leaf extract vitex trifolia against Indian adult worms (Pheretima posthuma) by petri dish method

\begin{tabular}{|c|c|c|c|}
\hline \multirow[t]{2}{*}{ Groups } & \multirow[t]{2}{*}{ Worms } & \multicolumn{2}{|l|}{ (In min) } \\
\hline & & Time taken for paralysis (in min) & Time taken for paralysis mean \pm SEM \\
\hline \multirow[t]{4}{*}{ Solvent Blank } & $\mathrm{A}$ & - & - \\
\hline & $\mathrm{B}$ & & \\
\hline & $\mathrm{C}$ & & \\
\hline & $\mathrm{D}$ & & \\
\hline \multirow{4}{*}{ Piperazine Citrate $10 \mathrm{mg} / \mathrm{ml}$} & A & 20.45 & $21.58 \pm 0.61$ \\
\hline & $\mathrm{B}$ & 21.03 & \\
\hline & $\mathrm{C}$ & 21.54 & \\
\hline & $\mathrm{D}$ & 23.32 & \\
\hline \multirow[t]{4}{*}{$25 \mathrm{mg} / \mathrm{ml}$} & A & 14.11 & $13.78 \pm 0.68$ \\
\hline & $\mathrm{B}$ & 12.24 & \\
\hline & $\mathrm{C}$ & 15.49 & \\
\hline & $\mathrm{D}$ & 13.31 & \\
\hline \multirow[t]{4}{*}{$50 \mathrm{mg} / \mathrm{ml}$} & A & 4.51 & $5.79 \pm 0.52$ \\
\hline & $\mathrm{B}$ & 6.09 & \\
\hline & $\mathrm{C}$ & 7.01 & \\
\hline & $\mathrm{D}$ & 5.58 & \\
\hline \multirow{4}{*}{$100 \mathrm{mg} / \mathrm{ml}$} & A & 5.01 & $4.57 \pm 0.27$ \\
\hline & $\mathrm{B}$ & 4.11 & \\
\hline & $\mathrm{C}$ & 4.08 & \\
\hline & $\mathrm{D}$ & 5.10 & \\
\hline
\end{tabular}

Each value was represented as mean $\pm S E M, n=6$ independent experiments

\section{In silico docking studies results}

In silico docking studies of the 11 selected phytoconstituents of $V$. trifolia were carried out with phosphoethanolamine methyltransferase (4FGZ).

The selected phytoconstituents had various types of functional groups and most of the functional groups possessed good phosphoethanolamine methyltransferase inhibitor activity. Among them, Abietatriene-3-ol showed higher phosphoethanolamine methyltransferase inhibitory activity. Moreover among the selected 11 compounds, two compounds showed binding energy value between- 6 to-7 $\mathrm{kcal} / \mathrm{mol}$, three compounds showed values between-7 to-8 $\mathrm{kcal} / \mathrm{mol}$, four compounds showed values between- 8 to- $9 \mathrm{kcal} / \mathrm{mol}$, a compound showed values between- 9 to-10 $\mathrm{kcal} / \mathrm{mol}$ and another compound showed values above-10 $\mathrm{kcal} / \mathrm{mol}$ (table 3).

Table 3: Docking parameters of compounds in phosphoethanolamine methyltransferase (4FGZ)

\begin{tabular}{llll}
\hline Ligands & Binding energy (kCal/mol) & Inhibitory constant $(\boldsymbol{\mu M})$ & Intermolecular energy $(\mathbf{k C a l} / \mathbf{m o l})$ \\
\hline Phosphoethanolamine & -6.03 & $38.29 \mu \mathrm{M}$ & -7.82 \\
Abietatriene-3-ol & -10.25 & $30.91 \mathrm{nM}$ & -10.84 \\
Artemetin & -7.33 & $4.26 \mu \mathrm{M}$ & -9.42 \\
Beta-sitosterol & -8.19 & $984.3 \mathrm{nM}$ & -10.28 \\
Dihydrosolidagenone & -9.3 & $152.9 \mathrm{~nm}$ & -10.49 \\
Friedelin & -7.28 & $4.58 \mu \mathrm{M}$ & -9.37 \\
Isovitexin & -6.56 & $15.65 \mu \mathrm{M}$ & -9.54 \\
Rotundiduran & -6.87 & $9.14 \mu \mathrm{M}$ & -8.66 \\
Vitetrifolin-A & -8.13 & $1.1 \mu \mathrm{M}$ & -8.73 \\
Vitetrifolin-B & -8.93 & $284.06 \mathrm{nM}$ & -11.02 \\
Vitetrifolin-C & -7.99 & $1.4 \mu \mathrm{M}$ & -9.78 \\
Vitexycarpin & -8.14 & $1.07 \mu \mathrm{M}$ & -10.23 \\
\hline
\end{tabular}


Table 4: Docking parameters of compounds and binding site in phosphoethanolamine methyltransferase

\begin{tabular}{|c|c|c|c|c|c|c|c|c|c|c|c|c|c|}
\hline & $\begin{array}{l}\text { Phosphoetha } \\
\text { nolamine }\end{array}$ & $\begin{array}{l}\text { Abietat } \\
\text { riene- } \\
3 \text {-ol }\end{array}$ & $\begin{array}{l}\text { Arte } \\
\text { metin }\end{array}$ & $\begin{array}{l}\text { Beta- } \\
\text { sitost } \\
\text { erol }\end{array}$ & $\begin{array}{l}\text { Dihydrosoli } \\
\text { dagenone }\end{array}$ & $\begin{array}{l}\text { Friede } \\
\text { lin }\end{array}$ & $\begin{array}{l}\text { Isovit } \\
\text { exin }\end{array}$ & $\begin{array}{l}\text { Rotundi } \\
\text { duran }\end{array}$ & $\begin{array}{l}\text { Vitetri } \\
\text { folin-A }\end{array}$ & $\begin{array}{l}\text { Vitetri } \\
\text { folin-B }\end{array}$ & $\begin{array}{l}\text { Vitetri } \\
\text { folin-C }\end{array}$ & $\begin{array}{l}\text { Vite } \\
\text { xin }\end{array}$ & $\begin{array}{l}\text { Vitexyc } \\
\text { arpin }\end{array}$ \\
\hline & 34 ASN & $14 \mathrm{LEU}$ & $10 \mathrm{ASP}$ & 19 TYR & $14 \mathrm{LEU}$ & $14 \mathrm{LEU}$ & 10 ASP & 10 ASP & 14 LEU & 10 ASP & 10 ASP & $\begin{array}{l}14 \\
\text { LEU }\end{array}$ & 19 TYR \\
\hline & 35 TYR & 19 TYR & $14 \mathrm{LEU}$ & 35 TYR & 63 GLY & 19 TYR & $\begin{array}{l}19 \\
\text { TYR }\end{array}$ & 14 LEU & 19 TYR & 62 ILE & 14 LEU & $\begin{array}{l}19 \\
\text { TYR }\end{array}$ & 31 PHE \\
\hline & 36 ILE & 36 ILE & 19 TYR & 36 ILE & 65 GLY & 37 SER & 36 ILE & 19 TYR & $63 \mathrm{GLY}$ & 63 GLY & 19 TYR & $\begin{array}{l}63 \\
\text { GLY }\end{array}$ & $34 \mathrm{ASN}$ \\
\hline & 37 SER & 63 GLY & 36 ILE & 37 SER & 85 ASP & 62 ILE & 37 SER & 62 ILE & 85 ASP & 85 ASP & 62 ILE & $\begin{array}{l}85 \\
\text { ASP }\end{array}$ & 35 TYR \\
\hline & 61 ASP & 85 ASP & 37 SER & 63 GLY & 86 ILE & $63 \mathrm{GLY}$ & 85 ASP & $63 \mathrm{GLY}$ & 86 ILE & 86 ILE & $63 \mathrm{GLY}$ & $\begin{array}{l}86 \\
\text { ILE }\end{array}$ & 36 ILE \\
\hline & 63 GLY & 86 ILE & 62 ILE & 64 SER & 111 ILE & $65 \mathrm{GLY}$ & 86 ILE & 84 ILE & 87 CYS & 111 ILE & 85 ASP & $\begin{array}{l}87 \\
\text { CYS }\end{array}$ & 37 SER \\
\hline & 64 SER & 90 ILE & 63 GLY & $66 \mathrm{LEU}$ & 129 ALA & 85 ASP & $\begin{array}{l}109 \mathrm{AS} \\
\mathrm{N}\end{array}$ & 85 ASP & 90 ILE & 132 HIS & 86 ILE & $\begin{array}{l}109 \mathrm{~A} \\
\text { SN }\end{array}$ & 38 SER \\
\hline & 66 LEU & 109 ASN & 65 GLY & 85 ASP & 132 HIS & 86 ILE & $\begin{array}{l}110 \\
\text { ASP }\end{array}$ & 86 ILE & $\begin{array}{l}109 \\
\text { ASN }\end{array}$ & $133 \mathrm{LEU}$ & 111 ILE & $\begin{array}{l}110 \mathrm{~A} \\
\text { SN }\end{array}$ & 61 ASP \\
\hline & $68 \mathrm{GLY}$ & 110 ASP & 85 ASP & 86 ILE & $133 \mathrm{LEU}$ & 90 ILE & $\begin{array}{l}111 \\
\text { ILE }\end{array}$ & 110 ASP & 110 ASP & & 132 HIS & $\begin{array}{l}111 \\
\text { ILE }\end{array}$ & $63 \mathrm{GLY}$ \\
\hline & $69 \mathrm{GLY}$ & 111 ILE & 86 ILE & $\begin{array}{l}\text { ARG } \\
127\end{array}$ & & 111 ILE & $\begin{array}{l}128 \\
\text { ASP }\end{array}$ & 111 ILE & 111 ILE & & $133 \mathrm{LEU}$ & $\begin{array}{l}112 \mathrm{~L} \\
\mathrm{EU}\end{array}$ & 64 SER \\
\hline & & 129 ALA & 90 ILE & $\begin{array}{l}128 \\
\text { ASP }\end{array}$ & & $\begin{array}{l}128 \\
\text { ASP }\end{array}$ & $\begin{array}{l}129 \mathrm{AL} \\
\mathrm{A}\end{array}$ & 129ALA & 129 ALA & & & $\begin{array}{l}128 \\
\text { ASP }\end{array}$ & 65 GLY \\
\hline & & 132 HIS & $\begin{array}{l}128 \\
\text { ASP }\end{array}$ & $\begin{array}{l}129 \\
\text { ALA }\end{array}$ & & 129ALA & $\begin{array}{l}132 \\
\text { HIS }\end{array}$ & 132 HIS & 132 HIS & & & $\begin{array}{l}129 A \\
\text { LA }\end{array}$ & 66 LEU \\
\hline & & $133 \mathrm{LEU}$ & $\begin{array}{l}129 \\
\text { ALA }\end{array}$ & 132 HIS & & 132 HIS & & 133LEU & 133LEU & & & $\begin{array}{l}132 \mathrm{H} \\
\text { IS }\end{array}$ & $68 \mathrm{GLY}$ \\
\hline & & & 130 & 133 & & 133 & & & & & & $133 \mathrm{~L}$ & $69 \mathrm{GLY}$ \\
\hline & & & $\begin{array}{l}\text { ILE } \\
133 \\
\text { LEU }\end{array}$ & LEU & & LEU & & & & & & EU & 85 ASP \\
\hline & & & & & & & & & & & & & $\begin{array}{l}128 \text { ASP } \\
132 \text { HIS } \\
160 \text { TYR } \\
181 \text { TYR }\end{array}$ \\
\hline A & -6.03 & -10.25 & -7.33 & -8.19 & -9.3 & -7.28 & -6.56 & -6.87 & -8.13 & -8.93 & -7.99 & -0.33 & -8.14 \\
\hline B & $38.29 \mu \mathrm{M}$ & $30.9 \mathrm{~nm}$ & $\begin{array}{l}4.26 \mu \\
M\end{array}$ & $\begin{array}{l}984.3 \\
\mathrm{~nm}\end{array}$ & $152.9 \mathrm{~nm}$ & $4.58 \mu \mathrm{M}$ & $\begin{array}{l}15.65 \mu \\
M\end{array}$ & $9.14 \mu \mathrm{M}$ & $1.1 \mu \mathrm{M}$ & $\begin{array}{l}284.06 n \\
M\end{array}$ & $1.4 \mu \mathrm{M}$ & $\begin{array}{l}570.7 \\
5 \mathrm{~m}\end{array}$ & $1.07 \mu \mathrm{M}$ \\
\hline $\mathrm{C}$ & -7.82 & -10.84 & -9.42 & -10.28 & -10.49 & -9.37 & -9.54 & -8.66 & -8.73 & -11.02 & -9.78 & -3.32 & -10.23 \\
\hline
\end{tabular}
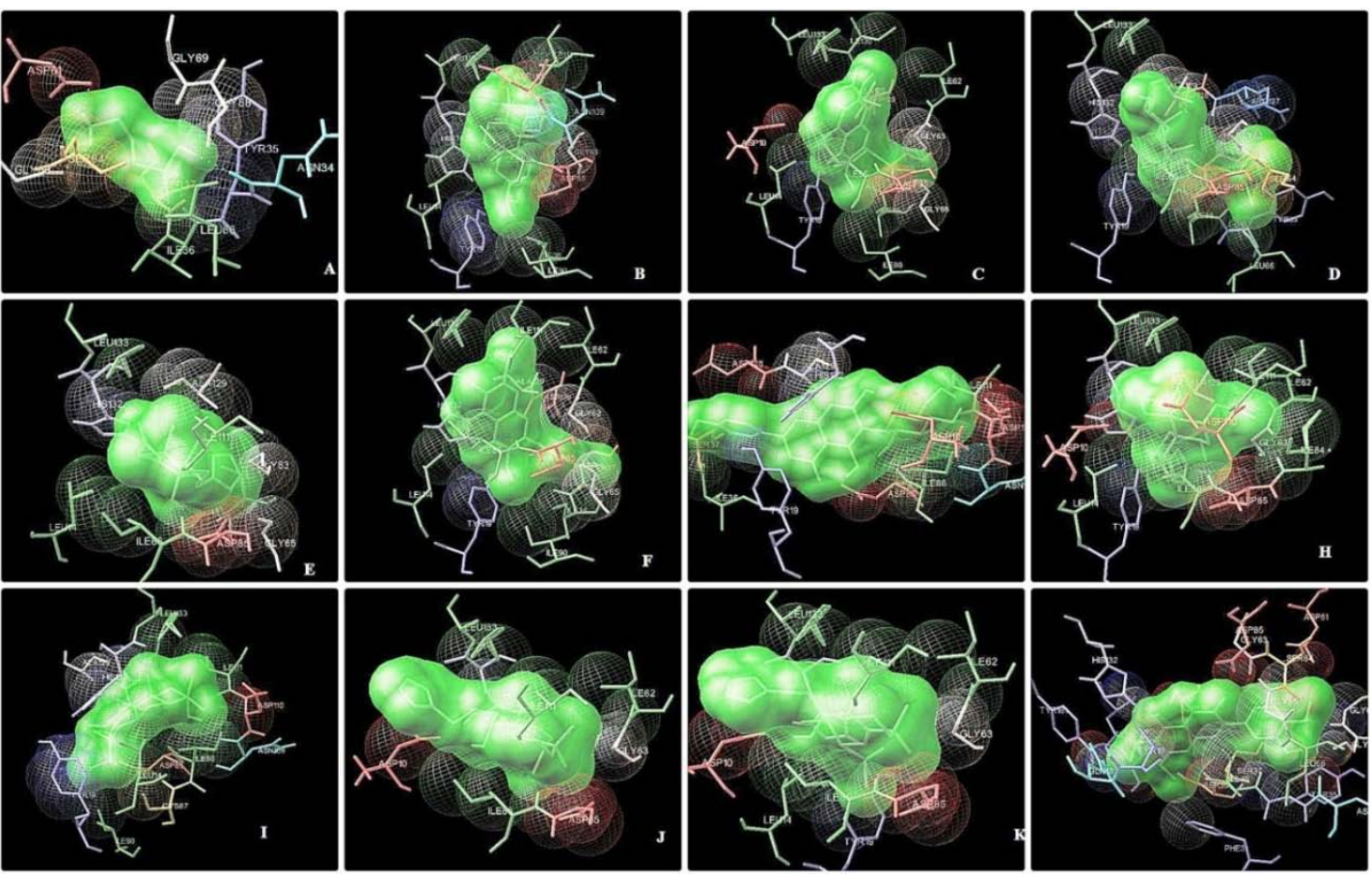

Fig. 4: Docked pose of phosphoethanolamine methyltransferase (4FGZ) with phosphoethanolamine and phytoconstituents of Vitex trifolia linn, A-Phosphoethanolamine, B-Abietatriene-3-ol, C-Artemetin, D-Beta-sitosterol, E-Dihydrosolidagenone, F-Friedelin, G-Isovitexin, HRotundiduran, I-Vitetrifolin-A, J-Vitetrifolin-B, K-Vitetrifolin-C, L-Vitexycarpin 
Binding energy $=\mathrm{A}+\mathrm{B}+\mathrm{C}-\mathrm{D}$

where, $A$ indicates the sum of intermolecular energy, Wandervalls energy ( $\mathrm{vdW}$ ), hydrogen bonds, desolvation energy and electrostatic energy $(\mathrm{kcal} / \mathrm{mol})$, final total internal energy $(\mathrm{kcal} / \mathrm{mol})$ denoted as a $\mathrm{B}$, the torsional free energy $(\mathrm{kcal} / \mathrm{mol})$ mentioned as $\mathrm{C}$, unbound system's energy ( $\mathrm{kcal} / \mathrm{mol})$ marked as a D. In addition, various parameters like inhibitory constant $\left(\mathrm{K}_{\mathrm{i}}\right)$, intermolecular energy, electrostatic energy, total internal energy, torsional energy, unbound external energy, cluster RMS and ref RMS were determined. Inhibition constant $\left(\mathrm{K}_{\mathrm{i}}\right)$ is directly proportional to the binding energy. When the compounds inhibitory activity increased, there was a decrease in its binding energy. Similarly, intermolecular energy is directly proportional to the binding energy, i.e., lesser the intermolecular energy, lesser the binding energy. The other parameters like electrostatic energy, total internal energy, torsional energy, unbound external energy, cluster RMS and ref RMS is independent of the binding energy. The values of standard compound phosphoethanolamine (value of A-binding energy, Binhibition constant, C-intermolecular energy).

Binding energy, inhibitory constant $\left(\mathrm{K}_{\mathrm{i}}\right)$, inter molecular energy (--6.03 $\mathrm{kcal} / \mathrm{mol}, 38.29 \mu \mathrm{M},-7.82)$, were compared to abietatriene-3-ol (-10.25 $\mathrm{kcal} / \mathrm{mol}, \quad 30.91 \mathrm{nM},-10.84)$, dihydrosolidagenone $(-9.3 \mathrm{kcal} / \mathrm{mol}$, 152.9nM,-10.43), vitetrifolin-B $(-8.93 \mathrm{kcal} / \mathrm{mol}, 284.06 \mathrm{nM},-11.02)$ (table 4). Among the selected compounds, abietatriene-3-ol, dihydrosolidagenone and vitetrifolin- $B$ possess very potent phosphoethanolamine methyltransferase inhibitory activity.

\section{DISCUSSION}

Preliminary phytoconstituents of $V$. trifolia methanolic extract revealed the presence of alkaloids, coumarins, flavonoids, terpenoids polyphenols, saponins, and tannins. Also, this plant was proved to possess various active phytoconstituents $[5,6,14]$.

In the antibacterial test, The total methanolic leaves extract of $V$. trifolia was screened for its antibacterial activity against organisms such as Shigella, Staphylococcus, streptococci, Streptococcus pneumoniae (gram-positive) Haemophilusinfluenzae, klebisella, Proteusvulgaris and Salmonellatyphi (gram-negative) by Kirby-Bauer disc diffusion method. The antibacterial study revealed that (table 1) the total methanolic extract exhibited antibacterial activity, even in low concentration $(4 \mathrm{mcg} / \mathrm{disc})$. At $16 \mathrm{mcg} /$ disc the extract showed a significant antibacterial effect, compared to blank and other concentrations. The antibacterial activity may be due to the presence of phytoconstituents such as alkaloids, flavonoids and phenolic compounds in this plan [20].

In the anthelmintic activity, the Indian earthworms (Pheretima posthuma) are invertebrates composed of many segments. A thin mucilaginous outer layer covered the earthworm, which is made up of complex polysaccharides. It is very essential for the free movement of earthworm. Any damage in the outer layer would restrict the movement due to paralysis [32,33]. Anthelmintic drugs either kill or paralyze the worm. Normally, worms do not store energy, and energy is derived from the host by glucose uptake mechanism. Also, most of the drugs cause either flaccid paralysis through chloride ion channel by GABA mechanism or spastic paralysis through the cholinergic mechanism. When worms are paralyzed, they lose their ability to gripping power and are expelled through the gut with the help of the peristaltic movement. The drug may also affect the normal function of the worms by binding the glycoprotein present in the cuticle of the parasite and cause paralysis [34]. The earthworms moved normally, spontaneously this movement was recorded on kymograph. The mechanism of the most anthelmintic drug is paralysis of the worms. The paralyzed worms are expelled from the large intestine. Based upon this principle, worms were treated with saline, Piperazine citrate $(10 \mathrm{mg} / \mathrm{ml})$ and various concentrations of total methanolic leaf extract of $V$. trifolia. In the Petri dish method, the total methanolic extract of $V$. trifolia showed the mean paralyzing time of Pheretimaposthuma with a dose of 25,50 and $100 \mathrm{mg} / \mathrm{ml}$ were found to be $13.78,5.79$ and $4.57 \mathrm{~min}$ respectively. In the meantime of Piperazine citrate at a dose of 10 $\mathrm{mg} / \mathrm{ml}$ causes paralysis in the above helminth in $21.58 \mathrm{~min}$. In organ bath method time for paralysis (seen as a decrease in spontaneous movement and no movement respectively) of the worm as recorded on a slow-movingSherrington rotating drum. In saline treatment, worms are not paralyzed so it produced normal spontaneous movement for a long time, it serves as a control response, Piperazine citrate is a known anthelmintic drug, in this treatment worm are paralyzed for a short time, it serves as a standard reference. Then the time required to paralyze the worms in various concentrations of plant extract was noted. This time was compared to the standard and control-treated animal. From the above study, it was seen that the total methanolic leaf extract of $V$. trifolia showed a dosedependent anthelmintic activity as compared to a standard drug Piperazine citrate. The worms paralyzing time was decreased at increasing concentration of the extract. Total methanolic leaf extract of $V$. folia produced a potent anthelmintic activity against the Pheretima posthuma when compared to reference standards.

In molecular docking studies, once compounds were successfully docked with an enzyme, the enzyme/ligand complex was analyzed. The analysis was based on various parameters such as hydrogen bond interactions, $\Pi-\Pi$ interactions, binding energy, and RMSD. It gives information as to, whether the compounds were bound on active site or not $[35,36]$. Normally, the thumb rule indicates that compounds bound in the active site of the enzyme by both hydrogen bond and $\Pi-\Pi$ hydrophobic interactions, which means that compounds have significant biological activities. From the molecular docking studies, the potential binding sites of the phosphoethanolamine were clearly shown (table 4) and they were found to be 34 ASN, 35 TYR, 36 ILE, 37 SER, 61 ASP, 63 GLY, 64 SER, $66 \mathrm{LEU}, 68 \mathrm{GLY}, 69 \mathrm{GLY}$. This proves that the effective binding sites are bound with the selected phytoconstituents when compared with the phosphoethanolamine. It proves that the selected compounds have the ability to inhibit the phosphoethanolamine methyltransferase enzyme. The flavonoids displayed binding energy ranging between-6.56 kcal $/ \mathrm{mol}$ to- $10.25 \mathrm{kcal} / \mathrm{mol}$. All the selected compounds showed less significant binding energy when compared to phosphoethanolamine $(-6.03 \mathrm{kcal} / \mathrm{mol})$. This proves that the phytoconstituents of $V$. trifolia Linn have a potential phosphoethanolamine methyltransferase inhibitory activity when compared to phosphoethanolamine. The molecular docking studies revealed (table 4) that most active compound abietatriene-3-ol was bound to the following sites 36 ILE, 90 ILE, 19 TYR, 14 LEU, 132 HIS, 85 ASP, 129 ALA, 86 ILE, 63 GLY, 133 LEU, 111 ILE, 110 ASP and 109 ASN. The potential binding sites of the phosphoethanolamine were clearly found to be, 34 ASN, 35 TYR, 36 ILE, 37 SER, 61 ASP, 63 GLY, 64 SER, 66 LEU, 68 GLY and 69 GLY (fig. 4). This proves that the effective binding sites are present in the compound abietatriene-3-ol compared with the phosphoethanolamine, in addition, selected compounds had the ability to inhibit phosphoethanolamine methyltransferase enzyme (table 3). Apart from that two more parameters such as inhibition constant $(\mathrm{Ki})$ and intermolecular energy were determined. The phytoconstituents of $V$. trifolia Linn showed inhibition constant, ranging from $15.65 \mu \mathrm{M}$ to $30.91 \mathrm{nM}$. The chosen compounds had less inhibition constant when compared to the phosphoethanolamine $(38.29 \mu \mathrm{M})$. The inhibition constant is directly proportional to binding energy and observed results indicated that the inhibition constant is decreased simultaneously if binding energy decreased. Thus, the phosphoethanolamine methyltransferase inhibitory activity of the phytoconstituents was found to be higher compared to phosphoethanolamine. The phytoconstituents showed intermolecular energy ranging between$8.66 \mathrm{kcal} / \mathrm{mol}$ to- $10.84 \mathrm{kcal} / \mathrm{mol}$ which was lesser when compared to the phosphoethanolamine $(-7.82 \mathrm{kcal} / \mathrm{mol})$. Intermolecular energy is also directly proportional to the binding energy. The observed results indicated that there was a decrease in the intermolecular energy of all the selected compounds with a simultaneous decrease in the binding energy. Based on the docking studies, the phosphoethanolamine methyltransferase inhibitory activity of the selected compounds was found to decrease in the order of Isovitexin, Rotundiduran, Friedelin, Artemetin, VitetrifolinC, Vitetrifolin-A, Vitexycarpin, Beta-sitosterol, Vitetrifolin-B dihydrosolidagenone, and abietatriene-3-ol. On the basis of the above study, abietatriene-3-ol and dihydrosolidagenone possess potential phosphoethanolamine methyltransferase inhibitor binding sites compared to that of the phosphoethanolamine. The results may 
be attributed due to differences in the position of the functional groups in compounds.

V. trifolia has various active phytoconstituents, particularly the methanolic extract contains alkaloids, coumarins, flavonoids, terpenoids polyphenols, saponins, and tannin. The antibacterial activity was screened to explore that the extract may directly attack the parasite or kill the parasite by stimulating the host defense mechanism. The performed in vitro anthelmintic evaluation report confirmed that the total methanolic extract showed significant anthelmintic activity by paralyzing the worm, due to the expected mechanisms such as cholinergic mediated acetylcholine release or direct binding of acetylcholine into the muscarinic or nicotinic receptor. The activation of the cholinergic receptor alters the normal depolarisation and repolarisation process and it leads to spastic paralysis. In the organ bath method, it was noticed that the worms had lost their contractile power, maybe due to flaccid paralysis. The flaccid paralysis caused by GABA mediated chloride ion flow through Clion channel and as a result reduces the muscle tone and causes weakness of the muscle. The in vitro anthelmintic evaluation report clearly indicates that the extracts showed their anthelmintic property in a dose-dependent manner which is effective in the treatment of helminthiasis, particularly against adult worm. In addition, to strengthen the data to move forward towards in vivo study the drug design screening was performed. In this study, we targeted the phosphoethanolamine methyltransferase enzyme, because the enzyme plays a vital role in the parasite life cycle and enzymecatalyzed methylation of phosphatases during the process of phosphatidylcholine biosynthesis. Phosphatidylcholine is essential for the formation of the plasma membrane in nematodes, thus phosphoethanolamine was used as a standard ligand, and all the selected compounds were docked with an enzyme. The observed results indicated that compounds had less binding energy was compared to phosphoethanolamine. It was so interesting that the docking studies also prove that the total methanolic extracts of $V$. trifolia and its active constituents showed a significant anthelmintic property.

\section{CONCLUSION}

Based on the study report, the authors revealed that the extract showed an anthelmintic effect and proved that the active constituents of $V$. folia have good phosphoethanolamine methyltransferase inhibitory activity. The report of antibacterial, in vitro and in silico anthelmintic studies confirmed that the total methanolic leaves extract of $V$. trifolia and its active constituents were having a significant anthelmintic property with the valuable information about its mechanisms of action. Thus $V$. trifolia active constituents have high significance to be considered as a potential drug candidate in the treatment of helminthiasis, furthermore, it has a great scope to be investigated on different animal models.

\section{ACKNOWLEDGMENT}

The authors are thankful to the Dr. R. Sutharsingh, Vice Principal and Head and also thankful to Mrs. M. Uvarani, Department of Pharmacognosy, S. B. College of pharmacy, Tamilnadu, India for their invaluable support.

\section{FUNDING}

Nil

\section{AUTHORS CONTRIBUTIONS}

This research work has been designed by Soundararajan Muthukrishnan and he act as a Principal investigator, Ragunath and Blessy Susan Varghese were executed this research work under the guidance of principal investigator.

\section{CONFLICT OF INTERESTS}

Declared none

\section{REFERENCES}

1. Witola WH, Kwame Matthews, Mark McHugh. In vitro anthelmintic eficacy of inhibitors of phosphoethanolamine methyltransferases in Haemonchus contortus. Int J Parasitol Drugs Drug Resist 2016;6:44-53.
2. Prichard RK. Anthelmintic resistance. Veterinary Parasitol 1994;54:259-68.

3. Meena AK, Singh U, Yadav AK, Singh B, Rao MM. Pharmacological and phytochemical evidences for the extracts from plants of the genus vitex-a review. Res 2010;2:1-9.

4. Padmalatha K, Jayaram K, Raju NL, Prasad MV, Arora R. Ethnopharmacological and biotechnological significance of vitex. Bioremediation Biodiversity Bioavailability 2009;3:6-14.

5. Chatterjee A, Prakashi SC. The treatise of Indian medicinal plants. New Delhi: National institute of science communication and information. Resources 1994;10:525.

6. Nair CK, Mohanan N. Medicinal plants of India. New Delhi: NAG Publishersl; 1997. p. 698.

7. Saxena ES, Pant MV, Sharma P. The usual plants of India. CSIR: New Delhi; 1992. p. 683.

8. Sreedhar V, Ravindranath LK, Gopal NM, Sanjithnath M. In vitro antioxidant activity and free radical scavenging potential of roots of vitex trifolia. Res J Pharm Biol Chem Sci 2010;1:1036-44.

9. Anandan R, Jayakar B, Kararn B, Babuji S, Manavalan R, Senthilkumar R. Effect of ethanol extract of flowers of vitex trifolia Linn. on CCL4 induced hepatic injury in rats. Pak J Pharm Sci 2009;22:391-4.

10. Manjunathan BK, Vidya SM, Krishna V, Mankani KL, Singh SD, Manohara YN. Comparative evaluation of wound healing potency of Vitex trifolia L and Vitex altissima L. Phytother Res 2007;21:457-61.

11. Li WX, Cheng-bin C, Cai B, Xin-sheng Y. Labdane-type diterpines as new cell cycle inhibitors and the apoptosis inducers from Vitex trifolia Linn. J Asian Nat Prod Res 2005;7:95-105.

12. Nair AGR, Ramesh P, Subramanian S. Two unusual flavones (artemetin and 7-desmethylartemetin) from the leaves of vitex trifolia. Curr Sci 1975;44:214-6.

13. Pan JG, Xu ZL, Fan JF. GC-MS analysis of essential oils from four vitex species. China J Chinese Mat Med 1989;14:357-9.

14. Ramesh P, Nair AGR, Subramanian SS. Flavone glycosides of vitex trifolia. Fitoterapia 1986;4:282-3.

15. Palavalli LH, Brendza KM, Haakenson W, Cahoon RE, McLaird M, Hicks LM, et al. Defining the role of phosphomethylethanolamine $\mathrm{N}$-methyl transferase from Caenorhabditis elegans in phosphocholine biosynthesis by biochemical and kinetic analysis. Biochemistry 2006; 45:6056-65.

16. Brendza KM, Haakenson W, Cahoon RE, Hicks LM, Palavalli LH, Chiapelli BJ, et al. Phosphoethanolamine- $\mathrm{N}$-methyltransferase (PMT-1) catalyses the first reaction of a new pathway for phosphocholine biosynthesis in Caenorhabditis elegans. Biochem J 2007;404:439-48.

17. Pessi G, Kociubinski G, Mamoun CB. A pathway for phosphatidylcholine biosynthesis in Plasmodium falciparum involving phosphoethanolamine methylation. Proc Natl Acad Sci USA 2004;101:6206-11.

18. Pessi G, Choi JY, Reynolds JM, Voelker DR, Mamoun CB. In vivo evidence for the fiwitgi of Plasmodium falciparum phosphoethanolamine methyltransferase and its coupling to the Kennedy pathway. J Biol Chem 2005;280:12461-6.

19. Witola WH, El Bissati K, Pessi G, Xie C, Roepe PD, Mamoun CB. Disruption of the Plasmodium falciparum PfPMT gene results in a complete loss of phosphatidylcholine biosynthesis via the serine-decarboxylase phosphoethanolamine-methyltransferase pathway and severe growth and survival defects. J Biol Chem 2008;283:27636-43.

20. Murgan M, Mohan VR. Efficacy of different solvent extracts of Vitex trifolia L. and Aristolochia indica L. for potential antibacterial activity. Sci Res Rep 2012;2:110-4.

21. Vigar Z. Atlas of medical parasitology. $2^{\text {nd }}$ Edn. Singapore; PG Publishing House; 1984. p. 216-7.

22. Jha NK, Kumar P. Molecular docking studies for the comparative analysis of different biomolecules to target hypoxia-inducible factor-1 1 I. Int J Appl Pharm 2017;9:83-9.

23. Vijayaraj S, KC Veena. Insilico studies of oxime prodrug of gliclazide against sulphonylurea receptors (SUR 1). Int J Curr Pharm Res 2017;9:100-3.

24. Bauer AW, Kirby WMM, Sherries SC, Turk M. Antibiotic susceptibility of testing by a standard single disc method. Am J Clin Pathol 1966;36:492-6. 
25. Thorn GW, Adams RD, Braunwald E, Issalbacher KJ, Petersdorf RG. Harrison's principles of internal medicine, New York: McGraw Hill Co; 1977. p. 1088-9.

26. Devi K, Indumathy S, Rathinambal V, Uma S, Kavimani S, Balu V. Anthelminthic activity of asta churna. Int J Health Res 2009;2:101-3.

27. Aryal A, S Upreti, K Das. Evaluation of anthelmintic activity of citrus reticulata: in vitro and its phytochemical investigation. Asian J Pharm Clin Res 2017;10:278-80.

28. Danquah CA, Koffuor GA, Annan K, Ketor KC. The antihelminthic activity of Vernonia amygdalina (Asteraceae) and Alstonia boonei de wild (Apocynaceae). J Med Biomed Sci 2012;1:21.

29. Sivashanmugam $T$, Muthukrishnan $S$, Umamaheswari $M$, Asokkumar K, Subhadradevi V, Jagannath P. Discovery of potential cholesterol esterase inhibitors using in silico docking studies. Bangladesh J Pharmacol 2013;8:223-9.

30. Umamaheswari $\mathrm{M}$, Madeswaran A, Asokkumar $\mathrm{K}$, Sivashanmugam AT, Subhadradevi V, Jagannath P. Docking studies: search for possible phytoconstituents for the treatment of gout. Int J Bio Pharm Res 2012;3:6-11.
31. Chaudhary SH, Verma MK, RK Gupta, A Kumar, AN El-shorbagi. Synthesis and investigation of anthelmintic, antibacterial and antifungal activity of 3,3-diphenyl propanamide derivatives. Asian J Pharm Clin Res 2019;12:310-5.

32. Lavanya B, Ramyakrishna PS, Nagarjuna S, Padmanabha YR. In vitro comparative study of anthelmintic activity of Brassica juncea and Brassica oleracea. J Pharm Res 2011;4:2907-9.

33. Chandrashekhar $\mathrm{CH}$, Latha KP, Vagdevi HM, Vaidya VP. Anthelmintic activity of the crude extracts of Ficus racemosa. Int J Green Pharm 2008;2:100-3.

34. Patel J, Kumar GS, Qureshi MS, Jena PK. Anthelmintic activity of ethanolic extract of whole plant of Eupatorium odoratum. Int J Phytomed 2010;2:127-32.

35. Park H, Lee J, Lee S. Critical assessment of the automated AutoDock as a new docking tool for virtual screening. Proteins 2006;65:549-54.

36. Sandeep G, Nagasree KP, Hanisha M, Kumar MMK. AUDocker LE: A GUI for virtual screening with AUTODOCK Vina. BMC Res Notes 2011;4:445-7. 